\title{
AC 2007-171: INTEGRATING STRUCTURAL FAILURES IN CONSTRUCTION ENGINEERING EDUCATION: IMPROVING THE PRACTICAL ASPECTS OF CONSTRUCTION PRACTICE
}

Virendra Varma, Missouri Western State University

Virendra K. Varma, Ph.D., P.E., F. ASCE, is professor of construction and chairman of the department of engineering technology at Missouri Western State University. 


\title{
Integrating Structural Failures in Construction Engineering Education: Improving the Practical Aspects of Construction Practice
}

\begin{abstract}
The Big Dig structural failure of July 10, 2006 in Boston's I-90 cut-and-cover connector tunnel roof that dropped a 10-ton module of concrete panels on a car killing a 38-year old woman called for Boston's Central Artery/Tunnel (CA/T) officials to probe installation of its tunnel support system. It has engaged the construction community on a national scale in asking how nine stainless steel anchors gave way causing the fatal air-plenum module collapse. In general, it has further led to questions surrounding applications of epoxy-threaded bolts. The construction engineering profession is alarmed that Boston's CA/T epoxy problem may be nationwide. What redundancy in design and construction in the structural support systems should be considered and how can public safety be insured? As engineering and construction professionals respond to structural failures of this nature, so do educators prepare to educate students to improve the practical aspects of engineering design and construction practices? To avoid future construction failures, educators have an ethical responsibility of educating students in modes and causes of structural failures, and the responsibilities for failures. This paper addresses lessons learned from failures of the past, such as, the very recent Boston's Big Dig Failure, the 1981 Collapse of Kansas City Hyatt Regency Hotel Skywalks, the 1978 Formwork Failure on West Virginia's Power Plant Cooling Tower, and a few other structural failures, and how such lessons can be incorporated in the classroom to teach students how to avoid construction failures in the future. As educators, it is concluded; we must teach students to strictly enforce review in design, and the associated change of design procedures including technical review and documentation. The author has incorporated construction failures as case studies in his senior classes, and recommends the approach of using past construction failures and the lessons learned to improve the practical aspects of engineering design and construction practice.
\end{abstract}

\section{Introduction}

In June 2006, in a building collapse in Clinton, Missouri, a town of some 9500 people, a 32-yearold leader of the Elks Club, lost his life. The century-old Elks Lodge was a three-story brick building that collapsed partially without warning. Lodge members, as they were getting ready for the meeting after dinner, heard a snap. With in a few seconds of hearing the snap, it was later reported by the 50 survivors, that the third story of the building collapsed on to the second without any warning. Unfortunately, the 32-year-old leader who had gone to the third floor to rehearse for the initiation ceremony that evening for the new members of the Elks Lodge perished in the collapse. Nine men were trapped for hours in the debris. It took about five hours to rescue the nine trapped in the rubble. What caused the failure of the century-old low-rise three-story brick building? The building housed men's clothing store, a law firm, and a pharmacy, and was not subjected to any unusual heavy loads. It is though quite fortunate that the collapse occurred at a time when the only business that was going on was a dinner meeting for an initiation ceremony. There could have been many more deaths had the collapse occurred during the regular business hours. What did the owners learn from the collapse, and what impact did it 
have on public works officials, engineers and contractors? What lesson did such a failure teach engineering and construction educators? And what did our construction students learn from it? There was neither an earthquake nor a tornado nor a heavy downpour that caused the collapse of the building. Then what was it that caused the structural failure and how can we avoid similar failures in the future.

Not long after the June 2006 structural failure in Missouri, another failure occurred. In July 2006, concrete ceiling panels fell in Boston's I-90 cut-and-cover connector tunnel. From the tunnel's roof, a 10-ton module of concrete panels dropped on a car killing a 38-year old woman. It called for Boston's Central Artery/Tunnel (CA/T) officials to probe installation of its tunnel support system. It has engaged the construction community on a national scale in asking how nine stainless steel anchors gave way causing the fatal air-plenum module collapse. In general, it has further led to questions surrounding applications of epoxy-threaded bolts. The construction engineering profession is alarmed that Boston's CA/T epoxy problem may be nationwide. What redundancy in design and construction in the structural support systems should be considered and how can public safety be insured? As engineering and construction professionals respond to structural failures of this nature, so do educators prepare to educate students to improve the practical aspects of engineering design and construction practices? To avoid future construction failures, educators have an ethical responsibility of educating students in modes and causes of structural failures, and the responsibilities for failures.

This paper addresses lessons learned from failures of the past, such as, the very recent Boston's Big Dig Failure, the 1981 Collapse of Kansas City Hyatt Regency Hotel Skywalks, and the 1978 Formwork Failure on West Virginia's Power Plant Cooling Tower, and how such lessons can be incorporated in the classroom to teach students how to avoid construction failures in the future. As educators, it is concluded; we must teach students to strictly enforce review in design, and the associated change of design procedures including technical review and documentation.

\section{Integrating Structural Failures In Engineering and Construction Education}

The author has incorporated construction failures as case studies in his senior classes, and recommends the approach of using past construction failures and the lessons learned to improve the practical aspects of engineering design and construction practice. Just as in the medical profession, doctors study the failed human specimens and diseased tissues and enlighten their entire profession to help alleviate the human suffering, so should be the responsibility of engineers, contractors, and educators to communicate the causes of structural and construction failures to their profession and to the students. This paper raises awareness that practice of engineering and construction can be improved through dissemination of information about the important structural failures to all the stakeholders of the profession, which includes students, educators (faculty), practicing engineers, contractors, codes and standards officials, public works officials, and construction inspectors. A case study approach based on lessons learned to integrate structural failures in the civil engineering and construction curriculums is a viable approach to improving the practical aspects of engineering design and construction practice.

\section{Case Study I: Boston’s 'Big Dig' Tunnel Failure}


On July 10, 2006, the collapse of a concrete ceiling panel in the I-90 connector tunnel killed one motorist. On December 23, 2006, after nearly six months of the tunnel failure, the Big Dig's Interstate 90 west-bound tunnel re-opened after federal inspectors approved the repairs to the damaged tunnel. The contractor, and his workers, spent several months testing and reinforcing epoxy-threaded bolts that would keep the ceiling panels suspended. The repairs to the tunnel cost approximately \$34 million.

The death of the 38-year-old motorist Milena Del Valle who was crushed under the 10-ton module of concrete ceiling panels is under the radar of state and federal criminal investigations. The State of Massachusetts is in the process of filing a multimillion-dollar civil lawsuit against design and contracting companies that worked on the Big Dig highway tunnel. It is claimed that their negligence led to the ceiling failure that killed Milena Del Valle. According to Massachusetts Attorney General Tom Reilly, 15 firms involved in the management, design, construction or oversight of the Interstate 90 would be named in the negligence lawsuit but only one, project manager Bechtel/Parsons Brinckerhoff, would face the gross negligence claim.

\section{Why Gross Negligence?}

It is claimed that Bechtel/Parsons Brinckerhoff knew early on about problems with the epoxy bolt system used to secure 4,500-pound concrete ceiling panels and had evidence of epoxythreaded bolts slipping or failing but still turned over the tunnel to the Massachusetts Turnpike Authority without warning of the "potentially dangerous situation." According to Tom Reilly, "The clock was ticking. The fuse was lit. It was just a matter of time until tragedy occurred."

\section{Probing the 'Big Dig' Structural Failure}

In order to learn from a structural failure, it is important that maximum amount of information is gathered and analyzed. The following steps are necessary to examine and report on a structural failure:
a. Determine the cause or causes of failure.
b. Determine the mode or modes of failure.
c. Determine the responsible parties involved in the failure.
d. Document all information, data, and analysis in the form of a report.
e. Disseminate information on the failure to the engineering, architectural, and contracting professions in a timely manner.

In regard to Boston's Big Dig tunnel failure, federal and state officials took upon themselves to inspect all sections of Boston's Central Artery/Tunnel project, and conducted tests on bolts that held the suspended panels and ventilation fans. In a matter of six months, they reinforced suspect sections of the tunnel with newly-designed redundant bolting systems that did not rely on epoxysecured bolts so that the tunnel could be re-opened to the public.

The possible causes/modes of the failure can be summed up as follows: ${ }^{2}$ (As reported in CE News, September 2006) 
- During inspection, many loose bolts were found throughout the tunnels.

- Design changes that resulted in the use of heavier concrete ceiling panels in the failed connector tunnel instead of lighter-weight panels used in the other adjacent Ted Williams Tunnel.

- The lack of steel supports in sections of the connector tunnel ceiling to which bolts holding the concrete panels could have been connected.

- Possible tunnel damage caused by blast vibrations from nearby construction of a 14story office tower.

- Use of diamond-tipped drill-bits, instead of carbide bits, in drilling holes for the bolts supporting the ceiling panels (epoxy may not hold as well in smoother holes drilled with diamond bits).

- The impact of cold weather during installation of the epoxy-bolt system in some tunnel sections.

Soon after the failure, the probe of the structural failure followed the appropriate steps. Bechtel/Parsons Brinckerhoff who acted as management consultant for the \$14.6 billion, 20-year project known as the Big Dig, issued a statement immediately after the accident expressing its support for a

"prompt, non-partisan, expert, and objective review of the entire CA/Tunnel project..........that this review cover the entire range of potential safetyrelated issues, including.......suspended ceilings,.....support systems,.... and the adequacy of operational inspection/maintenance. Supporting concrete ceiling panels by anchoring bolts to the roof with epoxy adhesive is widely and successfully used throughout the public transportation industry. Determining the causes of this specific failure will require a thorough forensic analysis of design, methods, materials, procedures, and documentation." 3

\section{Lesson Learned From the Big Dig Failure}

Although the exact cause of the failure can not be pin-pointed with a 100 percent certainty, it was quite clear from a report from the National Transportation Safety Board (NTSB) that 20 of the epoxies anchors (5/8-inch-diameter, stainless steel threaded studs approximately 8 inches long) had pulled out from the tunnel's roof in the area of the ceiling collapse. The standard recast concrete ceiling panels in the failure area were 12 feet wide, 8 feet long, and about 4 inches thick. During the rehabilitation phase of repairing the damaged tunnel, suspect sections of the tunnel were reinforced with newly designed redundant bolting systems that don't rely on epoxysecured bolts. One important lesson that the engineering profession can learn from this is that it is extremely important to build redundancy in structural support systems especially when it comes to suspended systems. As is often said, a structural designer may find a 3/16-inchdiameter rod sufficient to carry the tension load in a tension rod but may use 5/16-inch-diameter rod instead to build extra capacity and redundancy in the structure, or provide two 3/16-inchdiameter rods to be completely safe. This aspect of psychological and structural redundancy should be brought to the attention of students of architecture, engineering, and construction by engineering and construction educators. 


\section{Case Study II: Hyatt Regency Hotel Failure in Kansas City}

On July 17, 1981, the walkways at the Hyatt Regency Hotel in Kansas City, Missouri, failed. Records show that 114 people died from injuries as they fell with the walkways or were crushed underneath the walkways. More than 180 people were injured. Ironically, the Hyatt Hotel had opened for business only a year ago. In terms of design and construction time that it took to build the most modern hotel in Kansas City, it took two years to design the hotel, and two years to complete the construction.

The collapse of two suspended walkways in the Kansas City Hyatt Regency Hotel was the worst accident due to a structural failure in the history of the United States. Among the many theories offered for the cause of the collapse of the walkways, which included the dancing of too many people on the walkways, the National Bureau of Standards confirmed the cause to be a single change in the design of a support detail of the walkways. During investigation of the failure, it was discovered that the as-built support detail differed from the original design of the support. According to the Attorney General of Missouri, it was a case of "gross negligence," and subsequently, the structural engineer lost his professional engineering license.

The walkway system design was not only under-designed but also had no in-built redundancy. Redundancy provides reserve of strength in structures and it wasn't there in the design of Hyatt Regency Hotel walkways. Some may view it as a violation of public safety. The design change in the support detail was suggested by the contractor to simplify construction of the walkways. Unfortunately it was unnoticed by the design engineers, and resulted in the failure of the walkways.

\section{Why Gross Negligence?}

Some of the broad conclusions reported in the report on the Hyatt Regency Hotel walkways' failure were as follows:

a. The walkways collapsed under loads substantially less than those specified by the Kansas City Building Code.

b. All the fourth-floor box beam-hangar connections were candidates for initiation of walkway collapse.

c. Neither the quality of workmanship nor the materials used in the walkway system played a significant role in initiating the collapse.

According to the Attorney, at the time, of Missouri State License Board of Professional Engineers, "It got built without anybody ever figuring out if it would be strong enough. It just slipped through the cracks." The structural engineer's license was revoked because he was responsible for the design.

\section{Lesson Learned from the Hyatt Regency Hotel Failure}


Hyatt Regency Hotel failure was one of the greatest structural failures in the history of the United States, and it was a tragedy that killed 114 people, and injured 180 people. Many were maimed for the rest of their lives. Design engineers were found to be at fault because they failed to see the difference between their design and the design suggested by the contractor to simplify the construction. Seemingly no thorough review was done by the design engineers. The lesson from this tragedy is simple: "Don't Make Haste in Review. Contractor can wait." As educators, there is nothing more important than to instill in students the value of performing calculations. According to Missouri State licensing board attorney, "Nobody ever did any calculations to figure out whether or not the particular connection that held the skywalks up would work." How can this be an acceptable approach when engineers and contractors are responsible for designing and constructing safe public structures? To practitioners and educators, it is a continuing wakeup call that our students must value code compliance, appropriate review, and be taught the art of methodical, complete, neat, and thorough calculations. In his classes on analysis of structures, and design courses related to steel, wood, concrete, and masonry, the author always tries to insure that his students follow the detailed procedures in their calculation work.

\section{Case Study III: Cooling Tower Formwork Failure}

On April 27, 1978, a jack-up formwork system on a power plant cooling tower in West Virginia collapsed. It was the worst construction accident in U.S. history. Fifty-one construction workers fell 168 feet to their death. The construction workers were standing on a movable formwork system about 170 feet above the ground when the entire form suddenly peeled away from the newly placed concrete of the tower. Occupational Safety and Health Administration (OSHA) investigators "virtually ruled out" any fault in the ganged jump forms. The probable cause was directed toward concrete, the hoist used to raise it inside the tower, the method of jacking the formwork and design of the concrete structure. ${ }^{4}$

As reported in Engineering News Record (ENR), dated May 4, 1978.......

Workers were placing a 5-ft lift of concrete when the interior work platform peeled away. The formwork used on this Pleasants Station near St Marys was a patented formwork and had been used successfully on 36 towers completed by the same company over the last seven years. The concrete was a 5,400 psi mix and contained a high early strength additive. The forms were secured to a lift that was 24 hours old and one below it was placed 72 hours earlier. A day had been lost due to rain in the contractor's work schedule. When the formwork failed, it brought down all the fresh concrete and most of the day-old lift below it. The three-day-old ring stayed intact. The weather had been cold and rainy but during the week prior to the failure, temperatures were in 60 s during the day and in the 30 s at night. ${ }^{5}$

The probable cause was the green concrete. According to one electrician on the job, "They jacked that up on green concrete." However, the testing laboratory results showed that concrete cylinders did not show any unusual results. Since the workers were paid for a full day's work no matter how long it took them to place a lift, it is possible that there could have been a cause for them to rush more than they should have on that particular lift. 
Since OSHA listed several possible causes for the construction failure in its report, it was almost impossible to pinpoint the cause of the failure with any certainty. Proper procedures were not followed and human error was blamed in the Cooling Tower failure. Also it was pointed out that the formwork was not adequately secured to the wall. OSHA questioned the quality of concrete, and also a hoisting cable that was pulling a concrete bucket to a crane at the time of failure resulting in the possible progressive failure.

\section{Was There Gross Negligence?}

The contractor had a good track record on the same type of patented formwork and had used successfully on 36 towers over the last seven years. So, it was not a case of gross negligence but a human error. The weather may have played a part, and some wrong judgments were made.

\section{Lesson Learned from the Cooling Tower Formwork Failure}

Jump forms at the top of the St Marys Cooling Tower structure tore loose, and pulled work platforms and concrete down. Even though a number of men leaped into a safety net outside the tower, they got pulled in and died in the jumbled mess. One lesson that comes from dealing with concrete at an early age, and especially when additives are a part of the concrete mix, is that one should not try to hurry with the removal or jacking up the forms to maintain the speed of construction. Even if a contractor is ahead of the schedule, the contractor should be cautious with challenges posed by the green concrete and the fluctuations in weather. And then there is always an unknown factor.......the performance of a hoist cable. It is important for design engineers, contractors, and educators to disseminate information on how to avoid construction failures, and warn students what role each variable has the potential of playing in ultimate safety of the structure under construction. In this regard, teaching students about possible pitfalls to avoid during construction is an important element for integration in the curriculum.

\section{Conclusion}

Had the structural design engineers noticed the difference between the contractor's design to simplify construction detail of the walkway support system and their own original design, the Hyatt Regency Hotel failure may not have occurred. Had the design engineers of the Hyatt skyways done a thorough review and done thorough calculations and complied with the Code's intent, the gruesome tragedy could have been avoided. Had the project management team of the Big Dig tunnel built redundancy in the structural support system of the ceiling panels, the failure could have been avoided. Had proper construction procedures been followed on West Virginia's Cooling Tower formwork, lives of 51 people could have been saved. Past structural failures can teach practitioners, educators, and students that failures can be avoided. It requires dissemination of information to all the professions concerned on a timely and an on-going basis. Educators need to make sure that relevant information on construction failures is communicated and taught to students of engineering design and construction. Lessons learned from the past construction failures have a major impact on current and future professionals; therefore educators must teach students to strictly enforce thorough review in design, and appropriate documentation. As stated by Thomas Lewis, Project Engineer, E.I. Du Pont de Nemours \& Co., Buffalo, New York, "The Hyatt walkway design switch exemplifies the need for a strictly enforced change-of-design 
procedure including technical review and documentation. Technical people sometimes feel this procedure is a burden and does not apply to them. Then we see examples where the procedure was not followed."

As a foot-note to the lesson learned from the Hyatt Regency Hotel failure, the hotel was repaired with in five months of the collapse, and the three walkways were replaced by a single walkway at the second-floor level, which was not suspended but supported on 10 large reinforced concrete columns. ${ }^{7}$

\section{Bibliography}

1. Lavoie, D. "Massachusetts to Sue Big Dig Companies.” Associated Press, Nov. 28, 2006

2. "Investigators Probe Boston Central Artery/Tunnel design." CE News, September 2006, pp. 16-17.

3. Ibid.

4. Ross, Steven S. "Construction Disasters: Design Failures, Causes, and Prevention." McGraw-Hill Book Company, 1984.

5. Ibid

6. Ibid

7. Feld, J., and Carper K. “Construction Failure.” John Wiley \& Sons, Inc., 1997. 